
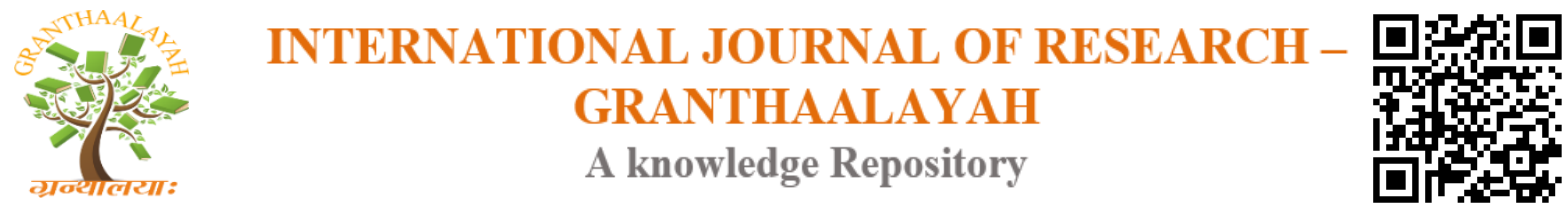

Science

\title{
PROXIMATE ANALYSIS OF FIVE COWPEA [(Vigna unguiculata (L.) Walp.)] LINES AS FEED RESOURCES FOR RUMINANT PRODUCTION IN BURKINA FASO
}

\author{
Barro Antoine 1, Batieno Téyouré Benoit Joseph ${ }^{2}$, Neya James Bougouma ${ }^{2}$, Palé \\ Korotoumou ${ }^{1,2}$, Jean Baptiste De La Salle Tignégré ${ }^{3}$, Kaboré Adama *2, Sawadogo \\ Mahamadou 4 \\ ${ }^{1}$ Université de Dédougou, BP 176, Dédougou, Burkina Faso \\ 2 Institut de l'Environnement et de Recherches Agricoles, BP 476, Ouagadougou, Burkina Faso \\ ${ }^{3}$ World Vegetable Center (AVRDC), BP 320, Bamako, Mali \\ ${ }^{4}$ Université Ouaga I Pr Joseph KI-ZERBO, 03 BP 7021, Ouagadougou 03, Burkina Faso
}

\begin{abstract}
The main food resource for ruminant production in Burkina Faso is natural grazing, which cannot sustain ruminant production all year round. Therefore, it is necessary to incorporate cultivated forages including crop residues such as fodder whose nutritional values must be verified before they are used in ruminant feed. To this end, samples of the fodder of five cowpea lines [(Vigna unguiculata (L.) Walp.)] created at the Saria station were analysed to determine their nutritional values using existing standard techniques. Obtained results revealed dry matter (DM) contents ranging from 91.12 to $91.50 \%$, organic matter (OM) from 83.05 to $90.20 \%$, crude protein $(\mathrm{CP})$ from $13.98 \%$ to 17.47 and crude fiber $(\mathrm{CB})$ from $26.45 \%$ to $31.85 \%$. Lines BC3F10P34-3 and $\mathrm{KVx} 745-11 \mathrm{P}$ contained the highest total nitrogen content and low average crude fiber values. Therefore, these two cowpea lines could be exploited in an appropriate feeding strategy for rural ruminant production.
\end{abstract}

Keywords: Cowpea Leaves; Nutritional Values; Ruminants; Burkina Faso.

Cite This Article: Barro Antoine, Batieno Téyouré Benoit Joseph, Neya James Bougouma, Palé Korotoumou, Jean Baptiste De La Salle Tignégré, Kaboré Adama, and Sawadogo Mahamadou. (2019). "PROXIMATE ANALYSIS OF FIVE COWPEA [(VIGNA UNGUICULATA (L.) WALP.)] LINES AS FEED RESOURCES FOR RUMINANT PRODUCTION IN BURKINA FASO." International Journal of Research - Granthaalayah, 7(5), 59-65. https://doi.org/10.29121/granthaalayah.v7.i5.2019.824.

\section{Introduction}

Burkina Faso has enormous potential for livestock production. According to Oudet (2005), agriculture and livestock occupy more than $85 \%$ of the population and contribute about $40 \%$ to the Gross Domestic Product (GDP) and $86.6 \%$ of the country's exports. Indeed, the livestock sector 
is characterized by the existence of a large and diversified livestock population (MRA, 2012), particularly ruminants which contribute to food security and poverty alleviation (MRA, 2010; Zerbo and Siri, 2012). However, ruminant farming faces multiple constraints, including animal feeding, a major difficulty for livestock farmers due to the lack of natural pastures in all seasons and the reduction of grazing areas. However, most of their breeding is extensive and depends on natural pastures for livestock feed. This is the reason for the considerable decline in animal productivity particularly that of ruminants in the dry season, mainly due to the quantitative and qualitative shortage of spatio-temporal fodder during this time of year (Kaboré-Zoungrana, 1995). One of the technical options to curb overgrazing and improve ruminant productivity during lean periods is to increase the use of agricultural by-products in animal feed, particularly legumes. Among these legumes, cowpea [(Vigna unguiculata (L.) Walp.)] is important because of his protein content, which varies from 20.5 to $31.7 \%$ (Onwuliri and Obu, 2002), and its vitamins and minerals values compared to herbaceous pastures that are poor in the dry season. It is a dual-use plant (forage and food) and its tops provide quality forage for livestock (Akundabwe et al., 1991). This study was carried out in this context to assess the nutritional values for livestock of five cowpea lines that were the subject of a recent agronomic evaluation study at the Saria experimental station (Barro et al., 2018). Specifically, this involves (i) determining the contents of the main chemical components of the leaves of the five cowpea lines in order to (ii) identify the best line for feeding ruminants.

\section{Materials and Methods}

\subsection{Study Site}

The study was carried out at the Saria and Kamboinsé research stations. 80 kilometres west of Ouagadougou, Saria is located. With geographical coordinates $12^{\circ} 16^{\prime} \mathrm{N}$ and $2^{\circ} 9^{\prime} \mathrm{W}$, the climate is of a North Sudanese type (Guinko, 1984). The soil is a ferric lixisol (FAO, 1989), with an average depth ranging from 50 to 80 centimetres. This depth is limited by the presence of concretionated armour (Zougmoré et al., 2004).

\subsection{Vegetal Material}

Five cowpea lines, KVx745-11P, KVx771-10G (Nafi), KVx775-33-2G (Tilgré), BC3F10P34-1 and BC3F10P34-3, constituted the study plant material created by INERA. The first three lines are already popularized and the last two, which are the descendants of line KVx745-11P, are in the process of popularization. Table I shows the characteristics of the five cowpea lines.

Table 1: Characteristics of the five cowpea lines studied.

\begin{tabular}{|l|l|c|c|c|c|}
\hline \multicolumn{1}{|c|}{ Lines } & \multicolumn{1}{|c|}{ Origin } & $\begin{array}{c}\text { Cycle } \\
\text { (in days) }\end{array}$ & Grain color & Grain size & $\begin{array}{c}\text { Grain yield } \\
\text { (Kg/ha) }\end{array}$ \\
\hline $\mathrm{KV} \times 745-11 \mathrm{P}$ & Burkina Faso & 70 & White & Small & 800 \\
\hline $\mathrm{BC}_{3} \mathrm{~F}_{10} \mathrm{P}_{34-1}$ & Burkina Faso & 70 & White & Small & ND \\
\hline $\mathrm{BC}_{3} \mathrm{~F}_{10} \mathrm{P}_{34-3}$ & Burkina Faso & 70 & White & Small & ND \\
\hline $\mathrm{KVx} 771-10 \mathrm{G}$ & Burkina Faso & 67 & White & Big & 2000 \\
\hline $\mathrm{KVx} 775-33-2 \mathrm{G}$ & Burkina Faso & 70 & White & Big & 2000 \\
\hline
\end{tabular}

ND: Not yet determined 


\subsection{Methodology Applied}

Five cowpea lines were each manually sown in a well delineated block after ploughing, followed by the levelling and shelving of the experimental plot. Each lineage has been labelled in its block. Maintenance operations consisted of weeding, applying N14P23K14 fertilizer to the first weeding at $100 \mathrm{Kg}$ per hectare, and insecticide treatments. Two insecticide treatments were required, one at flower bud formation and the other at pod formation to protect flowers and pods. The insecticide used was titan at a dose of $2 \mathrm{ml}$ per liter of water.

The following parameters were measured:

- dry matter (DM) which is obtained by drying the sample in an oven at $105^{\circ} \mathrm{C}$ for 24 hours (AOAC method, 1990);

- mineral matter (MM) or ash obtained by calcining $\mathrm{MS}$ in a muffle furnace at $550^{\circ} \mathrm{C}$ for 2 hours (AOAC method, 1990);

- organic matter $(\mathrm{OM})$ obtained by differentiating between DM and MM (AOAC method, 1990);

- crude protein (CP) obtained by the conventional Kjeldahl method, which includes a step of mineralization with concentrated sulphuric acid and a distillation step, followed by titration of the distillates. The $\mathrm{CP}$ is estimated by applying to the percentage of nitrogen, the coefficient 6.25 conventionally accepted;

- the parietal constituents, neutral detergent fiber (NDF), acid detergent fiber (ADF), acid detergent lignin (ADL) and crude fiber (CB) which are obtained by the method of Van Soest et al. (1991).

\subsection{Statistical Analyses}

The data collected were used to calculate the means ( \pm standard deviation) before being subjected to a one-way analysis of variance (ANOVA) followed by the separation of the means obtained by the 5\% Student Newman-Keuls test.

\section{Results and Discussions}

Table II presents the results obtained from the bromatological analyses of the hay samples of the five test lines and the levels of significance at the 5\% threshold for each chemical component determined between the cowpea lines in the study. These results show a slight variation in the chemical composition of the different lines. Indeed, obtained values ranged from $91.12 \%$ (BC3F10P34-3) to $91.50 \%$ (BC3F10P34-1) for DM; from 83.05\% (KVx745-11P) to 90.20\% (KVx775-33-2G) for MO ; from 9.80\% (KVx775-33-2G) to $16.95 \%$ (KVx745-11P) for MM; from $13.98 \%(\mathrm{KVx} 775-33-2 \mathrm{G})$ to $17.47 \%$ (BC3F10P34-3) for $\mathrm{CP}$ and from $26.45 \%(\mathrm{KVx} 745-11 \mathrm{P})$ to $31.85 \%$ (BC3F10P34-1) for BC. Lines BC3F10P34-3 (17.47\%) and KVx745-11P (14.8\%) contained the highest levels of crude protein. In addition, the average crude fibre value of all lines was relatively low.

The analysis of the bromatological values obtained shows that the lines studied are similar in terms of their dry matter (DM) content. The high MS rate would mean that the tops contain less water at the harvesting stage. According to Babatoundé (2005), ruminants must consume a certain amount 
of feed that must occupy a certain volume (the ingestion capacity), because the digestive tract only functions properly if it is sufficiently full. Thus, a sufficient amount of DM rich in energy can satisfy the needs of animals (Vandiest, 2005). The levels obtained for the DM of the lines (91.12$91.50 \%$ ) are similar to those of Nourou (2014) on four cowpea forage lines in Niger (91.22$92.70 \%$ ) and to the $90.9 \%$ DM of Wadré et al. (2015) for Cassia obtusifolia, a legume harvested by animals. In addition, these levels are lower than those of groundnut fodder (96.45\%) and sorghum straw (97.51\%) obtained by Kondombo and Nianogo (2001) and higher than those of Ouattara (2015), which obtained 86.14\% of DM for line KVx745-11P in Koumbia region of the country. This difference could be explained by soil and weather conditions and the time of harvest of the fodders.

For organic matter $(\mathrm{OM})$, the content of line BC3F10P34-3 $(86.51 \%)$ corroborates that obtained by Nourou (2014) for line TN256-87 (86.99\%). The OM of lines KVx771-10G, BC3F10P34-1 and $\mathrm{KVx} 775-33-2 \mathrm{G}$ are higher than those of its four lines. However, all our grades are lower than those of the Ndiambour $(91.40 \%)$, MelaKh $(90.98 \%)$, Mouride $(91.09 \%)$ lines obtained by Diouf (1998) and Khaya senegalensis (92.3\%) obtained by Ouédraogo (2006). This can be explained by both the soil and climate conditions and the varietal difference. With regard to mineral matter (MM), the contents of the lines studied (9.80-16.95\%) are much higher than those of Nourou (2014), which obtained contents varying between 5.22 and $7.88 \%$. They are also higher than those of Diouf (1998), ranging from $8.60 \%$ to $9.02 \%$, as well as those of several forage grazed in the dry season. This is the case for $6.92 \%$ of sorghum straw (Kondombo et al., 2001), 3.80\% of Faidherbia albida (Fall et al., 1997) and 6.50\% of Piliostigma reticulatum (Kiéma et al., 2008). In addition, the MM of line BC3F10P34-3 (13.49\%) is comparable to the $13.72 \%$ of groundnut fodders of Kondombo et al., (2001). The BC3F10P34-1 line (11.79\%) is comparable to the $11.52 \%$ of Cassia obtusifolia of Wadré et al. (2015), while the KVx745-11P line (16.95\%) is comparable to the $17.02 \%$ of Calotropis procera of Kanazoé (2015) and the $16.60 \%$ of K. senegalensis obtained by Doya (2016).

The crude protein (CP) contents of the five lines (13.98 - 17.47\%) obtained in the study are above the minimum nitrogen content $(7 \% \mathrm{DM})$ below which the rumen microflora cannot function efficiently (Kaboré-Zoungrana, 1995). These grades corroborate the results obtained by Ouattara (2015) with content higher than $15 \%$ at harvest, for KVx745-11P in pure culture and comparable to the $14 \%$ of Guiera senegalensis by Fall et al., (1997). These values are higher than those of Nourou (2014) and Diouf (1998) who found values of 12.18 to $13.09 \%$ and 11.10 to $16.09 \%$ respectively for other cowpea lines. They are also higher than the $3.85 \%$ of sorghum straws in Ouédraogo (1990), the $11.1 \%$ of groundnut vines and the $11.9 \%$ of cowpea vines obtained by Nantoumé et al., (2000). These values are higher than those of Nourou (2014) and Diouf (1998) who found values of 12.18 to $13.09 \%$ and 11.10 to $16.09 \%$ respectively for other cowpea lines. They are also higher than the $3.85 \%$ of sorghum straws in Ouédraogo (1990), the $11.1 \%$ of groundnut vines and the $11.9 \%$ of cowpea vines obtained by Nantoumé et al. (2000).

For cellulose, it is accepted that its use by ruminants is linked to the very functioning of the rumen and the richness of its population in microorganisms. The crude fiber (CB) contents of the five lines studied (26.45 to $31.85 \%$ ) are comparable to those (29.20 to 33.60\%) of Diouf (1998) on cowpea lines, to the $27.93 \%$ of P. reticulatum reported by Kiéma et al (2008) and to the $28.74 \%$ of C. obtusifolia reported by Wadré et al (2015). They are higher than those of Nourou (2014) who 
found values of 15.78 to $18.84 \%$ on cowpea lines and lower than the $42.99 \%$ contained in Andropogon gayanus and $48.21 \%$ in millet stems according to the results of Kiéma et al. (2012).

Table 2: Chemical composition of the fodders of the five lines studied

\begin{tabular}{|c|c|c|c|c|c|c|c|c|}
\hline \multirow[t]{2}{*}{ Lignées } & \multicolumn{8}{|c|}{ Chemical composition (\%) } \\
\hline & DM & OM & MM & MAT & CB & NDF & ADF & ADL \\
\hline $\mathrm{BC}_{3} \mathrm{~F}_{10} \mathrm{P}_{34-1}$ & $91,49 \pm 0,12^{\mathrm{a}}$ & $88,20 \pm 0,06^{\mathrm{b}}$ & $11,79 \pm 0,06^{\mathrm{d}}$ & $15,02 \pm 0,99^{\mathrm{b}}$ & $31,85 \pm 0,03^{\text {a }}$ & $47,57 \pm 0,44^{\mathrm{a}}$ & $29,65 \pm 0,54^{\mathrm{a}}$ & $5,90 \pm 0,20^{b}$ \\
\hline $\mathrm{BC}_{3} \mathrm{~F}_{10} \mathrm{P}_{34-3}$ & $91,12 \pm 0,23^{\mathrm{a}}$ & $86,50 \pm 0,09^{d}$ & $13,49 \pm 0,09^{b}$ & $17,46 \pm 0,01^{\mathrm{a}}$ & $27,76 \pm 0,33^{\mathrm{bc}}$ & $40,59 \pm 1,18^{\mathrm{c}}$ & $27,28 \pm 0,86^{b}$ & $5,74 \pm 0,34^{\mathrm{b}}$ \\
\hline KVx745-11P & $91,25 \pm 0,008^{a}$ & $83,61 \pm 0,29^{\mathrm{e}}$ & $16,73 \pm 0,29^{a}$ & $15,88 \pm 0,75^{b}$ & $26,44 \pm 0,58^{\mathrm{c}}$ & $43,68 \pm 0,38^{b}$ & $26,55 \pm 0,06^{b}$ & $5,31 \pm 0,25^{b}$ \\
\hline KVx771-10G (Nafi) & $91,16 \pm 0,02^{\mathrm{a}}$ & $87,55 \pm 0,05^{\mathrm{c}}$ & $12,44 \pm 0,05^{\mathrm{c}}$ & $14,34 \pm 0,49^{b}$ & $28,77 \pm 0,30^{\mathrm{b}}$ & $46,86 \pm 0,02^{a}$ & $28,79 \pm 0,45^{\mathrm{a}}$ & $6,61 \pm 0,09^{\mathrm{a}}$ \\
\hline KVx775-33-2G (Tilgré) & $91,47 \pm 0,07^{a}$ & $90,20 \pm 0,13^{\mathrm{a}}$ & $9,79 \pm 013^{\mathrm{e}}$ & $13,98 \pm 0,01^{b}$ & $27,24 \pm 0,56^{\mathrm{c}}$ & $42,15 \pm 1,11^{\text {bc }}$ & $25,79 \pm 0,07^{b}$ & $5,71 \pm 0,0^{\mathrm{b}}$ \\
\hline $\mathrm{P}$ & 0,0841 & 0,0000 & 0,000 & 0,0113 & 0,0003 & 0,0010 & 0,0025 & 0,0145 \\
\hline
\end{tabular}

$\mathrm{DM}=$ dry matter; $\mathrm{OM}=$ organic matter; $\mathrm{MM}=$ mineral matter; $\mathrm{CP}=$ crude protein; $\mathrm{CB}=$ crude fiber; $\mathrm{NDF}=$ neutral detergent fiber; $\mathrm{ADF}=$ acid detergent fiber; $\mathrm{ADL}=$ acid detergent lignin. (a b c d e) : Means with different letters on the same column are significantly different.

In addition, cellulose (carbohydrate), the main component of fodder, is believed to be totally indigestible for many animal species, particularly humans.

Finally, the results of parietal fibers show that the contents of Neutral Detergent Fiber (NDF) obtained (40.60 to $47.58 \%$ ) are low compared to 59.29\% of Kondombo et al, (2001) for groundnut fodders, $65.1 \%$ of G. senegalensis from Fall (1993) and $75.37 \%$ of sorghum straw measured by Nanéma (1998). However, they are higher than those of C. procera (29\%) obtained by Kanazoé (2015), Balanites aegyptiaca leaves (34.6\%) according to (Fall, 1993) and Boerhevia diffusa (38.9\%) measured by Doya (2016). The NDF rates of lines BC3F10P34-3 (40.60\%), KVx775-33$2 \mathrm{G}(42.15 \%)$ and $\mathrm{KVx} 745-11 \mathrm{P}(43.68 \%)$ are comparable to those of F. albida which contains $41.8 \%$ according to Fall (1997), K. senegalensis (43.3\%) after Doha (2016) and close to the results of Mbaw et al, (2013) with the leaves of Sterculia setigera (48.82\%) and Leucaena leucocephala (47.8\%). As for the parietal constituents, the contents of ADF (25.79 to 29.66) and ADL (5.32 to 6.61) obtained are lower than those of Nanéma (1998) studying sorghum straw (47.40\% of ADF and $7.04 \%$ of ADL). They are also lower than the $52.51 \%$ in ADF and $10.85 \%$ in ADL for groundnut fodders by Kondombo et al (2001). The levels of ADL are lower than the $13.9 \%$ of F. albida (Fall et al., 1997), the $15.3 \%$ of S. setigera (Mbaw et al., 2013) and the $29.1 \%$ of B. aegyptiaca leaves (Kaboré-Zoungrana et al., 2008). In general, lignins that are more or less strongly bound to parietal constituents are considered indigestible. As a physical barrier to microbial attack on the plant wall, they could cause a decrease in digestive efficiency in ruminants. It can then be assumed that the tops of the five lines studied, which were very poorly lignified at the harvesting stage, could therefore be digested entirely by ruminants to improve production.

\section{Conclusion}

This study highlighted the animal feeding potential of the fodder produced by the five cowpea lines at the Saria experimental station in Burkina Faso. All five lines, (KVx745-11P, KVx771-10G (Nafi), KVx775-33-2G (Tilgré), BC3F10P34-1 and BC3F10P34-3) have a good feed value for ruminants. However, BC3F10P34-3 would appear to be the best because it would contain more mineral material (13.49) and crude protein (17.47), and less fiber. By using this improved lineage, producers will benefit from a double interest, namely feeding their families (with seeds) and their ruminants (with fodder) in the dry season, a period of lack of quality fodder for ruminants. 
However, conservation techniques must be mastered in order not to distribute contaminated fodders to ruminants.

\section{Acknowledgements}

This research was conducted under the support of Innovation Lab for Climate Resilient Cowpea (ILCRC) funded by USAID. Thanks to the INERA for the technical and material supports provided.

\section{References}

[1] Akundabweni, LS., Paul, CP. and Singh, BB. Evaluation de lignées d'élite de niébé pour un usage double (feuilles/fourrage et graines). In: la recherche à Institut International d'Agriculture Tropicale (IITA) N³, 1991,6-7.

[2] AOAC (Association of Official Analytical Chemists. Official Methods of Analysis. Association of Official Analytical Chemists. (15th ed.). Washington, DC (1990), 1990.

[3] Babatoundé, S. Etude et prédiction de la valeur alimentaire de graminées et de légumineuses fourragères en zone tropicale humide du Bénin. Thèse de Doctorat Unique. Université de Liège (ULg) Agro-Bio Tech, Gembloux, 2005, 265 pages.

[4] Barro, A., Batieno, TBJ., Tignégré, JBDLS., Neya, JB., Palé, K., Kaboré, A., Ouédraogo, MH. and Sawadogo M. Evaluation of Agronomic Performances of Five Cowpea Lines in the Experimental Research Station of Saria, Burkina Faso. World Journal of Agricultural Research, 2018, 6(3): 8286

[5] Diouf, MN. Valorisation des résidus de récolte de niébé dans l'alimentation des animaux. Rapport technique Centre National de Recherches Agronomiques. 1998, 5 pages.

[6] Doha, YGA. Evaluation de l'utilisation de Khaya senegalensis et Boerhevia diffusa comme des alicaments dans la production ovine au Bénin. Thèse de Doctorat unique, Université d'Abomey Calavi, faculté des sciences agronomiques, Bénin. 2016, 151 pages.

[7] Fall-Touré, S., Traoré, E., N'Diaye, K., N'Diaye, NS. and Sèye B. M. Utilisation des fruits de Faidherbia albida pour l'alimentation des bovins d'embouche paysanne dans le bassin arachidier au Sénégal. Livestock Research for Rural Development 1997, 9 (5): 1-14.

[8] Guinko, S.. Végétation de la Haute-Volta. Thèse de Doctorat ès Sciences Naturelles. Université de Bordeaux III (France). Tome 1, 1984, 318 pages.

[9] Kaboré-Zoungrana, C. Composition chimique et valeur nutritive des herbacées et ligneux des pâturages naturels soudaniens et des sous-produits au Burkina Faso. Thèse de Doctorat d'Etat ès Sciences Naturelles, Université de Ouagadougou, Burkina Faso. 1995, 224 pages.

[10] Kanazoé, PO. Effets de différents niveaux de supplémentation des feuilles de Calotropis procera (Willd) R. Br. sur les performances de croissance et la charge parasitaire chez les ovins en saison pluvieuse au Burkina Faso. Mémoire de fin de cycle de la licence, Université Saint Thomas d'Aquin de Ouagadougou (USTA), Burkina Faso. 2016, 31 pages.

[11] Kiéma, A., Nianogo, AJ., Somda, J. and Ouédraogo, T.. Valorisation de Cassia obtusifolia L. dans l'alimentation des ovins d'embouche en région sahélienne du Burkina Faso. 2008, Tropicultura 26 (2): 98-103.

[12] Kiéma, A., Sawadogo, I., Ouédraogo, T. and Nianogo, AJ. Stratégies d'exploitation du fourrage par les éleveurs de la zone sahélienne du Burkina Faso. 2012, Int. J. Biol. Chem. Sci. 6(4): 14921505 .

[13] Kondombo, SR. and Nianogo, AJ. Performance d'ovins djallonké alimentés à base de résidus de récolte au Burkina Faso. 2001, Agronomie Africaine 13 (2): 59-66. 
[14] Mbow, MA., Traoré, EL., Diouf, M. and Akpo, LE. Valeurs bromatologique et nutritive de jeunes feuilles de Sterculia setigera Del. en milieu soudanien au Sénégal. 2013, Int. J. Biol. Chem. Sci, 7(1): 203-212.

[15] Ministère des Ressources Animales (MRA). Plan d'Actions et Programme d'Investissements du sous-secteur de l'élevage (PAPISE) 2010-2015. Ouagadougou/Burkina Faso. 2010, 73 pages.

[16] Ministère des Ressources Animales (MRA). Statistique du secteur de l'élevage. Ouagadougou/Burkina Faso. 2012, 151 pages.

[17] Nanéma, SL. Optimisation de l'utilisation des résidus de culture associés aux sous-produits agroindustriels dans l'alimentation des ruminants. Mémoire d'Ingénieur. I.D.R., Université Polytechnique de Bobo-Dioulasso, 1998, 63 pages.

[18] Nantoumé, H., Kouriba, A., Togola, D. and Ouologuem, B. Mesure de la valeur alimentaire de fourrages et de sous- produits utilisés dans l'alimentation des petits ruminants. 2000, Rev. Elev. Méd. Vét. 53 (3): 279-284.

[19] Nourou, AA.Analyse technico-économique de la production de quatre (4) variétés fourragères de niébé dans la station agronomique de l'INRAN et évaluation de la valeur alimentaire de ses fanes. Mémoire de master en productions animales et développement durable. Ecole Inter-états des Sciences et Médecine Vétérinaires de Dakar (E.I.S.M.V), 2014, 34 pages.

[20] Onwuliri, VA. and Obu, JA. Lipids and other constituents of Vigna unguiculata and Phaseolus vulgaris grown in northern Nigeria. Food Chemistry, 2002, 78 (1): 1-7.

[21] Ouattara, B. Performances agro-économiques de l'association maïs-niébé et analyse de la qualité de la biomasse fourragère à l'ouest du Burkina Faso. Mémoire d'ingénieur d'élevage. Centre Universitaire Polytechnique de Dédougou (C.U.P.D.) /Burkina Faso, 2015, 46 pages.

[22] Oudet, 2005. La révolution blanche est-elle possible au Burkina Faso, et plus largement en Afrique de l'Ouest? MISEREOR, Allemagne, 2005, 30 pages.

[23] Ouédraogo, CL. Influence du traitement des pailles à l'urée sur la croissance et la digestibilité chez les petits ruminants. Mémoire d'ingénieur d'élevage. I.D.R., Université de Ouagadougou, Burkina Faso. 1990, 74 pages.

[24] Ouédraogo, S. Potentialités fourragères et essais d'amélioration de la valeur nutritive de trois ligneux fourragers : Piliostigma thonningii Schumach Mile-Redh, Piliostigma reticulatum (D.C.) Hoscht et Khaya senegalensis (Desr) A. Juss. Mémoire d'Ingénieur du développement rural/IDR/Université Polytechnique de Bobo-Dioulasso, Burkina Faso. 2006, 145 pages.

[25] Van Soest, PJ., Robertson, JB. and Lewis, BA. Methods for dietary fiber, neutral detergent fiber and starch polysaccharides in relation to animal nutrition. 1991, J. Dairy Sci. 74: 3583-3597.

[26] Vandiest, P. Calcul des rations d'ovins. Filière ovine et caprine. $\mathrm{N}^{\circ} 11,2005,7$ pages.

[27] Wadré, S., Kaboré, A., Bayala, B., Traoré, A., Tamboura, HH. and Belem AMG. In vitro comparative anthelmintic activity on Haemonchus contortus of two natural fodders (Cassia obtusifolia and Piliostigma reticulatum) extracts used in Burkina Faso. International Journal of Agriculture and Forestry, 2015, 5 (2): 146-150.

[28] Zerbo, A. and Siri, D. Contribution de l'élevage à l'économie et à la lutte contre la pauvreté, les déterminants de son développement. 2012, 67 pages.

[29] Zougmoré, R., Mando, A.. and Stroosnijder, L. Effect of soil and water conservation and nutrient management on the soil-plant water balance in semi-arid Burkina Faso. Agricultural Water Management, 2004, 65: 103-120.

\footnotetext{
*Corresponding author.

E-mail address: ade1_bf@ yahoo.fr
} 